\title{
Ellipsis
}

2021

\section{Meeting Aunt Nebbi for the First Time}

Nikki Ummel

Follow this and additional works at: https://scholarworks.uno.edu/ellipsis

\section{Recommended Citation}

Ummel, Nikki (2021) "Meeting Aunt Nebbi for the First Time," Ellipsis: Vol. 46 , Article 10.

DOI: https://doi.org/10.46428/ejail.46.10

Available at: https://scholarworks.uno.edu/ellipsis/vol46/iss1/10

This Poetry is brought to you for free and open access by the Department of English and Foreign Languages at ScholarWorks@UNO. It has been accepted for inclusion in Ellipsis by an authorized editor of ScholarWorks@UNO. For more information, please contact scholarworks@uno.edu. 


\section{Meeting Aunt Nebbi for the First Time \\ by Nikki Ummel}

Button you up in my soul the way

I batten down

in my mother's

favorite jean jacket: frayed

at the edges but

functional, warm.

There is so much space, here

there is room. I need

to keep you close, until I learn

how you fit, discover

how we can stitch (disparate

patches)

together.

Tuck you up in my heart the way

I wear down

my mother's

picture in my pocket, faded at

the edges but

the resemblance, striking:

see my mother in your shoes, the ones you wore, funeral black but functional, worn.

I hope you have space for me, too.

I need to be kept close.

You wear her features well:

I squint, stare off

to the right, I see (second

chance to know)

her, too,

in you 
together.

Like two

black funeral

shoes. 